\title{
IMPACT OF TRANSPORTATION COSTS AND INFRASTRUCTURE QUALITY ON INDONESIAN IMPORTS
}

\author{
Tanti Novianti \\ Faculty of Economics and Management \\ Bogor Agricultural University \\ email: tantinovianti@yahoo.com \\ Yusman Syaukat \\ Faculty of Economics and Management \\ Bogor Agricultural University \\ Mangara Tambunan \\ Faculty of Economics and Management \\ Bogor Agricultural University \\ Pantjar Simatupang \\ Kementerian Pertanian Republik Indonesia
}

\begin{abstract}
This article investigates the impact of sea and air transportation cost, as well as infrastructure quality, to Indonesia's import. Employing a panel regression model to seek for the answer, the paper find that cost reduction for sea transportation has greater impact on the Indonesia's import volume compared to the air transportation. This paper also finds that Indonesia's infrastructure quality has a significant positive impact on Indonesia's import. The quality of ports, roads, and Linear Connectivity International Shipping (LSCI) are significant factors affecting import volume by sea transportation mode. Meanwhile, import volume by air transportation is significantly affected by the quality of the roads and airports.
\end{abstract}

Keyword: Transportation costs sea and air transportation infastructure qualities, volume of import JEL classification numbers: D24, H54, F13

DOI: http://dx.doi.org/10.20885/ejem.vol5.iss2.art1

\begin{abstract}
Abstrak
Paper ini menyelidiki pengaruh biaya transportasi laut dan udara dan kualitas infrastruktur erhadap impor Indonesia. Dengan menggunakan model regresi data panel, paper ini menemukan bahwa koefisien biaya transportasi untuk impor menggunakan transportasi laut lebih besar dibandingkan melalui udara. Dengan kata lain, turunnya biaya transportasi laut memiliki dampak yang lebih besar pada volume impor Indonesia dibandingkan melalui transportasi udara. Kualitas infrastruktur Indonesia memiliki dampak positif yang signifikan terhadap impor. Kualitas pelabuhan, jalan, dan Linear Connectivity International Shipping (LSCI) merupakan faktor penting yang dapat memengaruhi impor Indonesia melalui moda transportasi laut. Sementara itu, volume impor melalui moda transportasi udara dipengaruhi signifikan oleh kualitas jalan dan bandara udara.
\end{abstract}

Kata kunci: Biaya transportasi, kualitas infrastruktur laut dan udara, volume impor JEL classification numbers: D24, H54, F13

\section{INTRODUCTION}

The growing world economy since the end of the 20th century has increasingly opened trade and investment relations intercountries, and this is characterized by the increasingly open and rapid flow of goods 
and services across the countries so that the growth of world trade has increased. During the period of 1950-2004, the growth of world trade increased by an average of 5.9 percent per year. During the period of 20052011, the world export growth reached an average of 10 percent per year, while the world import growth reached 9 percent per year (WTO, 2012). Similarly, the contribution of trade to world GDP also increased from 25 percent in 1960 to 46 percent in 1999.

Indonesian trade in goods and services in the world markets shows fluctuated positive trends. Similarly, the contribution of export and import of goods and services to the Indonesian GDP for the last decade has tended to fluctuate ranging from 21 to 41 percent. The Indonesian imports especially include raw materials/auxiliary materials and capital goods.

Bergstrand (2001) stated that the revenue growth, declining tariffs and transport costs contribute to the growth of the world trade. Transportation costs have played an increasingly important role since the advent of trade liberalization where trade barriers for both tariffs and non-tariffs are reduced and even eliminated (Deardorff, 1995, and Limao and Venables, 2002). The transport costs depend on many factors, including the modes of transportation, quality of infrastructure, and geographic location (Kurmanalieva, 2006). The results of the UNTACD survey (2012) showed that the contribution of transportation modes of sea, air, and land were as much as $77,0.3$, and 16 percent of total world trade respectively.

Although most of the transport of goods is conducted by sea transportation, the recent developments indicate that the transport of goods by air transportation mode has also been increasing. During the period of 1975-2004, the traded goods by air grew by 7.4 percent per year, while those by sea transport grew relatively smaller namely 4.4 percent per year (Hummels, 2007). The c on- tribution of sea transport in the transport of goods is still very significant, especially for international cargo transportation. For the period of 2003-2007, the role of sea transport in international goods transport of Indonesia ranged from 87 to 93 per cent (Department of Transportation, 2008).

Although the reduction in transportation costs plays an important role in the growth of world trade, Porto (2005) states that the transportation costs are also most important trade barriers, especially for the developing countries. For example, in Indonesia, the transportation costs are still relatively very expensive, reaching 14.42 per cent of the total of production costs or 27 percent of GDP( Gross Domestic Product). These costs are among the highest the world. The research results by The Asia Foundation and LPEM UI research (2008) showed that sea transportation in Indonesia was very inefficient despite the fact that sea transport is a major supporter for international trade. The average cost of sea transport reached USD 0.54 per kilogram per kilometer. The high transport costs are partly due to poor infrastructure conditions. In Indonesia, the logistics cost from an industrial area to a port is higher than that in Malaysia. When compared with similar mileage, the cost of logistics in Indonesia reaches USD 750, but in Malaysia, it reaches only USA50.

Although tariffs and non-tariffs have been reduced and even abolished, and transportation costs are also likely to decline, not every country in the world experiences the same growth in trade. Like trade benefits, not all of the countries obtain the same benefits from trade. In addition to transportation costs, quality of infrastructure is also thought to affect the volume and pattern of trade including trade benefits. Obstacles such as transportation costs and quality of infrastructure will make both exported and imported goods become uncompetitive as they become more expensive for consumers and producers. Quality of infrastructure, par- 
ticularly domestic infrastructure, will determine the transportation costs from the border to both producers and consumers (imported goods) or from the producers to the border (exported goods). Transport infrastructure quality will also affect the time of export and import and ultimately affects the costs of export and import.

Based on the report of World Economic Forum (2011-2012), the quality of the Indonesian infrastructure is ranked $76^{\text {th }}$, but it is still relatively underdeveloped if compared to Singapore (ranked $2^{\text {nd }}$ ), Malaysia (ranked 26 ${ }^{\text {th }}$ ), and Thailand (ranked $42^{\text {nd }}$ ). Infrastructure of transportations is part of the logistics sector. Good logistics sector performance implies low costs of transport of goods, which in turn will increase the competitiveness of an economy. On the contrary, if the logistics performance is poor, the transportation costs will be high, so that economic competitiveness is low.

Based on the Logistics Performance Index (LPI) of World Bank (2011), in 2010 , Indonesia was ranked $75^{\text {th }}$ out of 155 countries surveyed (Table 2). This position is still relatively far below some of the neighboring countries such as Singapore, Malaysia, Thailand, Vietnam, and the Philippines which have similar geographical conditions as Indonesia (an archipelago). In regards to the logistics based on six categories measured in LPI, the performance of the Indonesia logistics is relatively worse than that of the five ASEAN countries. In almost all categories, except for timeliness, Indonesia is still relatively better than Vietnam. Customs and infrastructure are the two categories with the lowest values for Indonesia.

Table 1: The Comparison of the Quality of Infrastructure Pillar between Indonesia and ASEAN Countries, in 2009-2011

\begin{tabular}{lcccccccc}
\hline Infrastructure & \multicolumn{9}{c}{ Indonesia } & 2009 & $\mathbf{2 0 1 0}$ & $\mathbf{2 0 1 1}$ & Vietnam & Thailand & Philipines & Malaysia & Singapore \\
\hline Total of & 84 & 82 & 76 & 123 & 47 & 113 & 23 & 2 \\
Infrastructure & 94 & 84 & 83 & 123 & 37 & 100 & 18 & 2 \\
Road & 60 & 56 & 52 & 71 & 63 & 101 & 18 & 7 \\
Railway & Infrastructure & & & & & & & \\
Port & 95 & 96 & 103 & 111 & 47 & 123 & 15 & 1 \\
$\begin{array}{l}\text { Infrastructure } \\
\begin{array}{l}\text { Air transport } \\
\text { Infrastructure }\end{array}\end{array}$ & 68 & 69 & 80 & 95 & 32 & 115 & 20 & 1 \\
\hline
\end{tabular}

Source: World Economic Forum (2009-2012)

Table 2: Logistic Sector Performance of ASEAN Countries in Year 2010

\begin{tabular}{lrrrrrrr}
\hline Country & Custom & Infrastructure & $\begin{array}{c}\text { Intern } \\
\text { Service }\end{array}$ & $\begin{array}{c}\text { Logistic Sup- } \\
\text { porting Capacity }\end{array}$ & $\begin{array}{c}\text { Tracking and } \\
\text { Tracing }\end{array}$ & $\begin{array}{c}\text { Time } \\
\text { liness }\end{array}$ & LPI \\
\hline Singapore & 4.02 & 4.22 & 3.86 & 4.12 & 4.15 & 4.23 & 4.09 \\
Malaysia & 3.11 & 3.5 & 3.5 & 3.34 & 3.32 & 3.86 & 3.44 \\
Indonesia & 2.43 & 2.54 & 2.82 & 2.47 & 2.77 & 3.46 & 2.76 \\
Thailand & 3.02 & 3.16 & 3.27 & 3.16 & 3.41 & 3.73 & 3.29 \\
Philipine & 2.67 & 2.57 & 3.4 & 2.95 & 3.29 & 3.83 & 3.14 \\
Vietnam & 2.68 & 2.56 & 3.4 & 2.89 & 3.10 & 3.44 & 2.96 \\
Laos & 2.17 & 1.95 & 2.70 & 2.14 & 2.45 & 3.23 & 2.46 \\
Cambodia & 2.28 & 2.12 & 2.19 & 2.29 & 2.50 & 2.84 & 2.37 \\
Myanmar & 1.94 & 1.92 & 2.37 & 2.01 & 2.36 & 3.29 & 2.33 \\
\hline
\end{tabular}

Source: World Bank (2011) 
The position of Indonesia which lies on the trajectory between two continents and two oceans, and in the track of the world trade has implications on high trade volume by air and by sea. Therefore, the study on impact of the cost and quality of transportation infrastructure on trade, especially import volume of Indonesia was required to be conducted.

\section{Transportation Costs, Trade and Economy}

Trade transportation costs provide a very large direct influence on both domestic and international trades, namely, by increasing prices or commodities traded, both for the exporting and importing countries. Besides, transportation costs have also an indirect impact on the locations of production and the industrial centers, especially those with the international-scale. The existence of transportation costs does not change the basic principles of comparative advantage or trade advantage (for more discussion on comparative advantage, please see Davis and Weinstein (2003). However, because transport costs become a barrier to any movement of goods and services, this cost element contains the implications which are very important to the mechanism of an open world economy by various economic factors or variables Impact of infrastructure on trade costs especially the cost of transportation and trading volume can be seen in Figure 1

Based on Figure 1, it can be seen that the poor quality of infrastructure in a country which in this case is the exporting country (country 1) increased the cost of trade particularly transportation costs, thus increasing the overall costs of production so that the export supply $\left(S_{x}\right)$ decreased to $S_{x}^{\prime}$. Likewise, in the importing country (country 2), because the price of imported goods rose, the total of imports also decreased (from $D_{x}$ into $D_{x}^{\prime}$ ).

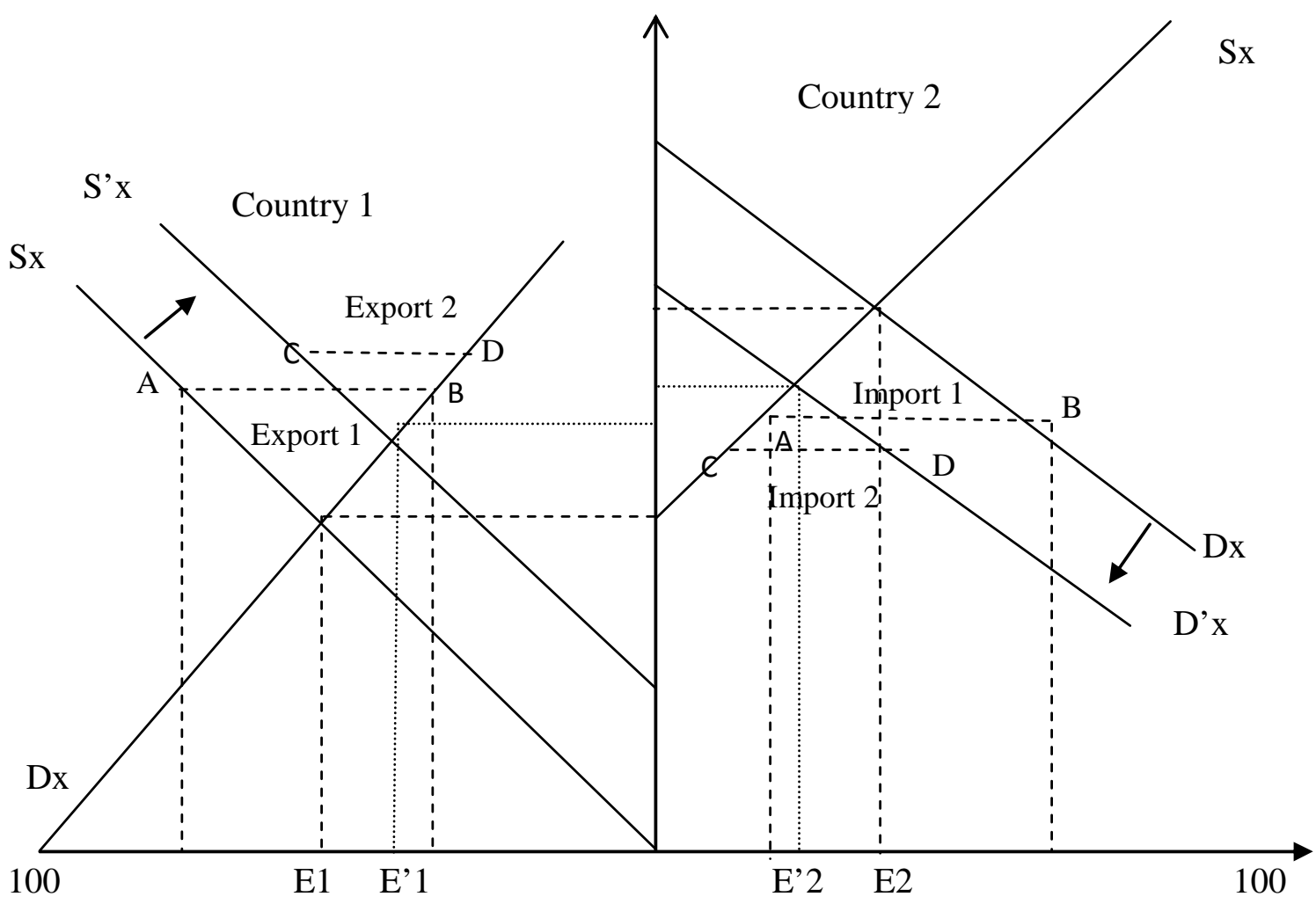

Figure 1. Impact of Infrastructur on Economy 
The quality of infrastructure, especially the quality of transportation infrastructure can influence the transportation costs Good quality of transportation infrastructure can reduce transport costs which will affect trade and economy (Kelejian and Robinson, 2006). Reduction of transportation costs will make the price of imported goods become cheaper so that the production costs of goods that use imported goods as intermediate inputs become cheaper. In regards to final products, the cheaper transport costs will lead to lower prices of products accepted by consumers. Cheaper export goods, intermediate goods and imported final goods will lead to the increase in demand for these goods (trade increases), which in turn can create jobs and promote economic growth.

Quality of infrastructure is also importance for building comparative advantage. Yeaple and Golub (2002) suggest that differences in the quality of public infrastructure inter-countries can explain the differences in the total factor productivity. In addition, because each sector is different in how it uses intensive services related to infrastructure and in how dependent they are on a good infrastructure, and the impact of infrastructure quality on the total factor productivity differs among sectors.

\section{METHODS}

\section{Types and Sources of Data}

The data used in this study include secondary data which were panel data from the 72 cross sections of the importing country of origin of Indonesia and six time series during the period of 2006 to 2011 which included the volume of imports, cif fob, GDP per capita, trade openness, and the index of infrastructure quality.

The trade data were obtained from the Central Bureau of Statistics based on sea and air transportation modes from the period of 2006-2011. The transportation cost data referred to what Limao and Ve- nables (2001) conducted namely using ad valorem of cif/fob for every mode of transportation while the other variable, namely GDP per capita was obtained from the World Bank. The data on the quality of overall infrastructure including transportation infrastructure, telecommunications and energy and infrastructure of transport (roads, ports airports) were obtained from Global Competiveness Report and World Economic Forum, while the data of the other infrastructure quality namely LSCI (Linear Connectivity International Shipping) was from obtained from the World Bank.

\section{Data Analysis Method}

The data obtained were analyzed descriptively and quantitatively. The descriptive analysis described the profiles of sea and air transport modes as well as the performance of Indonesia's bilateral trade based on transportation mode whereas quantitative analysis was used to see the impact of the quality of infrastructure and cost barriers to the import volume of Indonesia. The data processing method used in this study was a regression using pooled data with a fixed impact model.

\section{Models of Impact of Transportation Cost Barriers on the Indonesia Bilateral Trade}

$\ln \left(I_{i j, t}\right)=$ $\beta_{0}+\beta_{1} \ln T C i j+\ln \beta_{2}(\text { GDPcap })_{i t}+$ $\beta_{3} \ln \left(\right.$ GDP $\left._{\text {cap }}{ }_{j t}\right)+$ $\beta_{4}$ lntradeopeness $_{i t}+$ $\beta_{5}$ Lntradeopeness ${ }_{j t}+\mathrm{u}_{\mathrm{ijt}}$

where: $I_{i j, t}=$ importing country $i$ (importer/Indonesia) from country $j$ (country of origin of import/exporter) at $t$ time; $\beta_{0}=$ Constanta GDPcap GDPcap $\left._{j t}\right)=$ $G D P /$ capita of the country $i(j)$ year $t$; trade opennes $_{s}(j t)=$ openness $\{(X+M) / G D P\}$ of country $i(j)$ year $t ; \mathrm{u}_{\mathrm{ijt}}=$ error term 
Models of Impact of Quality of Infrastructure on Bilateral Trade of Indonesia

Model for sea transport mode is as follows:

$\ln \left(I_{i j, t}\right)=$

$\partial_{0}+\partial_{1} \ln T C i j+\partial_{2} \ln (\text { GDPcap })_{i t}+$

$\partial_{3} \ln \left(G_{D P C a p}\right)+$

$\partial_{4}$ ltor $_{\text {adeopeness }}{ }_{i t}+$

$\partial_{5}$ Lntradeopeness $_{j t}+\partial_{6}$ LnINFall $_{i t}+$

$\partial_{7}$ LniINFall $_{j t}+\mathrm{w}_{\mathrm{ijkt}}$

$\ln \left(I_{i j, t}\right)=$

$\partial_{0}+\partial_{1} \ln T C i j+\partial_{2} \ln (\text { GDPcap })_{i t}+$

$\partial_{3} \ln \left(\right.$ GDPcap $\left._{j t}\right)+$

$\partial_{4}$ ltor adeopeness ${ }_{i t}+$

$\partial_{5}$ Lntradeopeness $_{j t}+\partial_{6}$ LnINFjln $_{i t}+$

$\partial_{7} \operatorname{LnINFjln}_{j t}+\mathrm{w}_{\mathrm{ijkt}}$

$\ln \left(I_{i j, t}\right)=$

$\partial_{0}+\partial_{1} \ln T C i j+\partial_{2} \ln (\text { GDPcap })_{i t}+$

$\partial_{3} \ln \left(\right.$ GDPcap $\left._{j t}\right)+$

$\partial_{4}$ ltor adeopeness ${ }_{i t}+$

$\partial_{5}$ Lntradeopeness $_{j t}+\partial_{6} L_{S C I_{i t}}+$

$\partial_{7} L S C I_{j t}+\mathrm{w}_{\mathrm{ijkt}}$

$\ln \left(I_{i j, t}\right)=\partial_{0}+\partial_{1} \ln T C i j$

$+\partial_{2} \ln (\text { GDPcap })_{i t}$

$+\partial_{3} \ln ($ GDPcap $j t)$

$+\partial_{4}$ lntradeopeness $i t$

$+\partial_{5}$ Lntradeopeness $_{j t}$

$+\partial_{6}{I N F p l b n_{i t}}$

$+\partial_{7} I N F p l b n_{j t}+\mathrm{w}_{\mathrm{ijkt}}$

whereas Model for air transport mode is as follows

$\ln \left(I_{i j, t}\right)=\emptyset_{0}+\partial_{1} \ln (G D P c a p)_{i t}+$

$\emptyset_{2} \ln \left(G_{D P c a p}\right)+$

$\emptyset_{3}$ ltr adeopeness ${ }_{i t}+$

$\emptyset_{4}$ Lntradeopeness $_{j t}+\emptyset_{5}$ INFall $_{i t}+$

$\emptyset_{6}$ INFall ${ }_{j t}+\mathrm{v}_{\mathrm{ijkt}}$

$\ln \left(I_{i j, t}\right)=\emptyset_{0}+\partial_{1} \ln (\text { GDPcap })_{i t}+$

$\emptyset_{2} \ln \left(\right.$ GDPcap $\left._{j t}\right)+$

$\emptyset_{3}$ ltr adeopeness ${ }_{i t}+$

$\emptyset_{4}$ Lntradeopeness $_{j t}+\emptyset_{5} I_{N F j l n_{i t}}+$

$\emptyset_{6} I N F j \ln _{j t}+\mathrm{v}_{\mathrm{ijkt}}$

$\ln \left(I_{i j, t}\right)=\emptyset_{0}+\partial_{1} \ln (\text { GDPcap })_{i t}+$ $\emptyset_{2} \ln \left(G D P\right.$ cap $\left._{j t}\right)+$

$\emptyset_{3}$ lntradeopeness ${ }_{i t}+$

$\emptyset_{4}$ Lntradeopeness $_{j t}+\emptyset_{5}$ INFbndra $_{i t}+$

$\emptyset_{5} I N F b n d r a_{j t}+\mathrm{v}_{\mathrm{ijkt}}$

where: $I N F a l l_{i t(j t)}=$ infrastructure of the whole countries of $i$ and $j$; INFj $\ln _{i t(j t)}=$ infrastructure of the country roads of $i$ and $j$; $I N F p l b n_{i t(j t)}=$ infrastructure of ports; $L S C I_{i t(j t)}=$ level of connectivity of international shipping of the countries of $i$ and $j$; $I N F b n d r a_{i t(j t)}=$ infrastructure of ports of the countries of $i$ and $j$.

\section{RESULTS}

The results of the panel regression analysis generally indicate that every explanatory variable used consistently influences the bilateral trade by mode of transportation although the added variable does not affect the amount of the diversity value $\left(R^{2}\right)$ of each model, which has reached more than 98 percent. This indicates that the independent variables used in the model can explain more than 98 percent of the diversity of Indonesian imports using either sea or air transport mode.

\section{Impact of Transportation Mode-based Trade Transportation Costs on the In- donesian Imports}

Calculation of transportation costs referred to the study by Limao and Venables (2001) in which the ratio between the values of cost of insurance and freight (cif) and free on board (fob). According to Limao and Venables (2001), the costs of transportation of international trade consist of four items. Firstly, the costs of moving goods internationally (direct shipping), and secondly, information cost (cost of identifying potential trading partners). Thirdly, the costs of management and supervision, and lastly, the cost of time. 
Table 3:The Impact of Transportation Costs` on Indonesian Imports

\begin{tabular}{|c|c|c|c|c|}
\hline \multirow{2}{*}{ Variables } & \multicolumn{2}{|c|}{ Sea Transportation Mode } & \multicolumn{2}{|c|}{ Air Transportation Mode } \\
\hline & Coefficient & Std Error & Coefficient & Std Error \\
\hline LnTC & $-0.9985 * * *$ & 0.0366 & $-0.3724 * * *$ & 0.0317 \\
\hline LnGDPcap $_{i}$ & $3.1265^{* * *}$ & 0.5145 & $5.6633^{* * * *}$ & 0.9488 \\
\hline LnGDPcap $_{i}$ & $-3.1015 * * *$ & 0.5150 & $-5.5985 * * *$ & 0.9502 \\
\hline LnTradeOpeness $_{\mathrm{i}}$ & $-3.4513 * * *$ & 0.5228 & $-5.2115 * * *$ & 0.9311 \\
\hline LnTradeOpeness & $2.1870^{* * *}$ & 0.5204 & $4.5973 * * *$ & 0.9353 \\
\hline $\mathrm{C}$ & $15.3087 * * *$ & 0.5886 & $13.2852 * * *$ & 1.0201 \\
\hline Adjusted $\mathrm{R}^{2}$ & 0.9914 & & 0.9827 & \\
\hline S.Eof Regresion & 0.2498 & & 0.3118 & \\
\hline F- Statistic & 660.4934 & & 323.3011 & \\
\hline Prob (F -statistic) & 0.000000 & & 0.000000 & \\
\hline \multicolumn{5}{|c|}{ Fixed Impact (Cross Section) } \\
\hline Maximum & 3.7754 (Kuwait) & & 5.6642 (Qatar) & \\
\hline Minimum & 5.1176 (China) & & -8.396 (India) & \\
\hline
\end{tabular}

When compared with the tariff that has been thought to be the barriers for trade, ad valorem of transport costs by sea and air is relatively much higher. This is in accordance with what was stated by Hummels (2007). The growing trend of trade in the context of Asian countries will be higher by reducing transportation costs than by reducing tariffs. The estimation results of the impact of transport costs on imports Indonesian trade by sea and air transportation modes can be seen at Table 3. Table 3 shows that the transport costs of trade both by sea and air transportation modes have a negative impact on the volume of imports of Indonesia, indicating that if the trade transportation costs both by sea and air transport modes are cheaper, the volume of Indonesian imports will increase. The coefficient value of transportation costs by sea transportation mode is relatively larger than that of the transportation by air. The results are consistent with the results of the research by Pomfret and Sourdin (2009) showing that coefficient value of trade transportation costs is relatively greater for imports by sea transportation mode than that of the air transportation mode. This is related to the real conditions in which more than 95 percent (> 95\%) of the volume of Indonesian imports Indonesia is conducted by sea transportation, only a small fraction (about 1-4\%) is performed by air transportation mode (Badan Pusat Statistik, 2011).

Traded goods by sea transportation are generally bulky like oil and petroleum products, iron and iron ore, coal, and grain. Based on the data from the Badan Pusat Statistik (2011), the five categories with the largest import values during the first half of 2011 were machinery and mechanical appliances, machinery and electrical appliances, iron and steel, motor vehicles and their components, and organic chemicals. The role of these five categories on the total of non-oil and gas imports amounted to 47.5 percent with a growth rate of 25.0 percent.

Other explanatory variables thought to affect the import volume of Indonesia were the income per capita and trade openness. The estimation results indicate that the income per capita of the countries involved in trade (importers and exporters) has significantly influential on the volume traded. The income per capita of Indonesia as the importer country has positively affected trade, indicating that the higher the income per capita income of the people of Indonesia is, the higher the volume of imports will be. Based on the group of goods utilization, for the total of Indonesian imports, it is generally domi- 
nated by imported raw materials/auxiliary materials, followed by capital goods and consumption goods. When the coefficient value between air and sea transportation modes was compared, the coefficient of air transportation was much greater. This means that if there are changes income per capita in both importing country (Indonesia) and exporting country (the partner country of import origin), and changes in trade (import volume) seen from the mode of transportation will be greater in air transportation mode. It is thought to be related to the time delivery and high value goods. The higher the income of the people of the importing country, the faster delivery time will be asked by them, although the transport cost by air is relatively more expensive.

Trade openness variable (trade openness) of the importing origin country (exporter) is significantly positive on trade, indicating that if trade is more open, export volume of the importing origin country will be even greater. However, for the importing country, the openness will decrease its import volume. Thus, for the importing country, the benefits of this openness have not been able to be used optimally. This is allegedly associated with other determinants, which make the trade benefits received not optimal. This is reinforced by what was found from the research results of Chen and Gupta (2006) and Chang et al. (2009) who state that the positive impact of trade openness on economic growth is determined by the conditions and improvements on public infrastructure, financial sector, quality of human capital, labor market flexibility, as well as economic and price stabilities. These improvements will make trade openness take place effectively, thus increasing the efficiency of the allocation of the resources, allowing dissemination of knowledge and technology, and encouraging competition in domestic and international markets. This openness variable is an indicator commonly used to see how well a country is integrated in the international market.

\section{Impact of Barriers of Infrastructure Quality on the Indonesian Import Vo- lume by Modes of Transportation}

In this research, in order to see the impact of infrastructure on trade, the quality of the infrastructure used was the quality of the infrastructure from the Global Competitiveness Report of 2006-2011, namely the quality of overall infrastructure (including transport infrastructure, telecommunications, and energy) and the quality of individual transport infrastructure, which includes qualities of road infrastructure, port infrastructure, and air infrastructure, as well as LSCI (Linear Connectivity International Shipping). For sea transport mode (Table 4), the results of the analysis indicate that the quality of infrastructure in the importing country is significantly positive $(\alpha=$ $1 \%$ ) affecting the volume, amounting to 0.1158 . This means that if the quality of the overall infrastructure namely transport, energy and communication of Indonesia as the importing country becomes better, the trade (Indonesian imports) will increase. To further determine which type of quality of transport infrastructure is more powerful, the subsequent analysis was conducted to analyze the extent to which the quality of roads, ports airports, as well as LSCI is influential on Indonesian imports.

The estimation results indicate that of the three types of transport infrastructure analyzed, it can be seen that for sea transportation mode, infrastructure quality of ports of the importing country is relatively more influential on Indonesia imports namely 0.1774 . This is in accordance with Nordas and Piermartini (2004) who state that of all the qualities of infrastructure analyzed the quality of port infrastructure has the greatest impact on trade. The other infrastructure quality variables that is the quality of roads and LSCI of Indonesia as the importing country were positively influential namely 0.0815 and 0.0409 respectively. This indicates that better quality of roads and more connection with the network of international 
shipping will increase the volume of Indonesian imports. Road infrastructure in Indonesia has a vital role in national transportation serving approximately 92 percent of passenger transports and 90 percent of goods transports on the existing road network (Directorate General of Highways, 2010). For imported goods, good quality of roads will greatly assist the smooth distribution of goods and services from the port to the consumers.
Linear Connectivity International Shipping (LSCI) of Indonesia from 2004 to 2009 decreased by 1.3 percent from 25.9 (2004) to 25.7 (2009). While LSCI of other ASEAN countries such as Malaysia, Thailand, Vietnam and the Philippines showed an increase, with the greatest increase by Vietnam namely 13.9 percent (UNCTAD 2009). This condition should be given attention since LCSI is influential on Indonesian trade.

Table 4: Impact of Infrastructure Quality in Import Volume of Indonesia: Sea Transport Mode

\begin{tabular}{|c|c|c|c|c|}
\hline \multirow[t]{2}{*}{ Variables } & \multicolumn{4}{|c|}{ Sea Transport Mode } \\
\hline & All Infrastructure & Roads & LSCI & Ports \\
\hline LnTC & $-1.0156^{* * *}$ & $-1.0089 * * *$ & $-1.0088 * * *$ & $-1.0020 * * *$ \\
\hline Ln Gdpcap $_{i}$ & $2.6333 * * *$ & $2.6715^{* * *} *$ & $3.1044 * * *$ & $2.6276^{* * *}$ \\
\hline Ln Gdpcap $_{j}$ & $-2.6013 * * *$ & $-2.6560 * * *$ & $-3.0684 * * *$ & $-2.6415 * * *$ \\
\hline Lntradeopeness $_{\mathrm{i}}$ & $-3.5281 * * *$ & $-3.4545 * * *$ & $-3.4471 * * *$ & $-3.4814 * * *$ \\
\hline Lntradeopeness $_{\mathrm{j}}$ & $2.2675 * * *$ & $2.1974 * * *$ & $2.1677 * * *$ & $2.2396 * * *$ \\
\hline $\mathrm{INF}_{\mathrm{i}}$ & $0.1158 * * *$ & $0.0815^{* * *}$ & $0.0409 * * *$ & $0.1774 * * *$ \\
\hline $\mathrm{INF}_{\mathrm{j}}$ & -0.0223 & $0.0723 * * *$ & $-0.0027 * * *$ & 0.0342 \\
\hline Constanta & $14.7537 * * *$ & $14.5172 * * *$ & $14.3356^{* * * *}$ & $14.3783 * * *$ \\
\hline $\mathrm{R}^{2}$ Adjusted & 0.9896 & 0.9902 & 0.9895 & 0.9900 \\
\hline SE of Regression & 0.2435 & 0.2450 & 0.2459 & 0.2455 \\
\hline F-Statistic & 527.3939 & 564.4169 & 526.2692 & 550.3402 \\
\hline Prob (F-Stat) & 0.000000 & 0.000000 & 0.000000 & 0.000000 \\
\hline \multicolumn{5}{|c|}{ Fixed Impact (Cross Section) } \\
\hline Maximum & 3.5135 (Qatar) & 3.5102 (Qatar) & 3.8202 (Qatar) & 3.5145 (Qatar) \\
\hline Minimum & -5.0303 (Cina) & -4.9342 (Cina) & -4.9394 (India) & -4.9521 (China) \\
\hline
\end{tabular}

Table 5: Impact of Infrastructure Quality on Indonesian Import Volume: Air Transport Mode

\begin{tabular}{|c|c|c|c|}
\hline \multirow{2}{*}{ Variables } & \multicolumn{3}{|c|}{ Air Transport Mode } \\
\hline & Infrastructure $(A l l)$ & Road Infrastructure & Airport Infrastructure \\
\hline LnTC & $-0.3560 * * *$ & $-0.3486^{* * *}$ & $-0.3855^{* * *}$ \\
\hline $\mathrm{Ln} \mathrm{Gdpcap}_{i}$ & $3.6652 * * *$ & $3.7487 * * *$ & $5.5697 * * *$ \\
\hline $\operatorname{Ln~Gdpcap~}_{j}$ & $-3.5833^{* * *}$ & $-3.7195 * * *$ & $-5.2640 * * *$ \\
\hline Lntradeopeness $_{\mathrm{i}}$ & $-4.7450^{* * *}$ & $-4.6010 * * *$ & $-5.0332 * * *$ \\
\hline Lntradeopeness $_{\mathrm{j}}$ & $4.1808^{* * *}$ & $4.0460 * * *$ & $4.3866 * * *$ \\
\hline $\mathrm{INF}_{\mathrm{i}}$ & $0.3674 * * *$ & $0.3013^{* * *}$ & $-0.7637 * * *$ \\
\hline $\mathrm{INF}_{\mathrm{j}}$ & $-0.0879 * *$ & -0.0141 & 0.0800 \\
\hline Constanta & $10.7912 * * *$ & $10.8942 * * *$ & $15.4289 * * *$ \\
\hline $\mathrm{R}^{2}$ Adjusted & 0.9872 & 0.9843 & 0.9818 \\
\hline SE of Regression & 0.2962 & 0.3014 & 0.3047 \\
\hline F-Statistic & 427.8899 & 349.2376 & 299.7022 \\
\hline Prob (F-Stat) & 0.000000 & 0.000000 & 0.000000 \\
\hline \multicolumn{4}{|c|}{ Cross Section (Intersep Country) } \\
\hline Maximum & 5.0430 (Estonia) & 4.8726 (Estonia) & 5.6550 (Estonia) \\
\hline Minimum & -6.2574 (China) & -6.1320 (India) & -7.9272 (India) \\
\hline
\end{tabular}

Note: $* * *$ significant at the level of $1 \%$, ** significant at the level of 5\%, * significant at the level of $10 \%$ 
Similarly to the air transport mode, the infrastructure quality of Indonesia as an importing country, as a whole (transport infrastructure, telecommunications, and energy) also positively affects the trade, that is equal to 0.3674 . The results of the analysis of the quality of individual transport infrastructure show that the quality of the road infrastructure in the importing country has also a positive impact on trade, while the airport quality of Indonesia as the importing country has negativity impact on trade. This means that better quality of airports will reduce trade. This is presumably related to the relatively few trade goods transported by air; therefore, trade is inefficient. The traded goods traded transported by air are generally special commodities which are perishable or the buyers ask faster delivery time.

Other variables that also affect Indonesian trade by the air transportation mode include the GDP per capita of the importing country (Indonesia) and GDP per capita of the exporting country (partners), trade openness between Indonesian and the exporting country. The influence of each of these variables on the Indonesian international trade by air transportation mode is the same as those by sea transport mode. However, the impact of each of these variables to trade is greater by air than by sea.

The low quality of Indonesian infrastructure is associated with the relatively low budgets for infrastructure investment, especially since the economic crisis of $1997 / 1998$. Before the crisis, the allocation of the infrastructure funding reached more than 8 per cent of GDP; however, since the crisis of 1997/1998, the amount of budget has continued to decline. Although there has been an increase in the budget, it does not reach the same figure prior to the crisis of $1997 / 1998$.

\section{CONCLUSIONS}

The coefficient of transport costs for imports by sea transportation mode is relatively higher compared to the air transport mode. The decrease in the cost of transportation by sea has a greater impact on the volume of trade (imports) of Indonesia when compared to the cost of air transportation. Indonesian infrastructure quality as the importing country as a whole or individually, has a positive significant impact on trade (imports) in Indonesia. For the sea transport mode, infrastructure which is more influential includes the quality of the ports, roads, and Linear Shipping Connectivity Index (LSCI). As for air transport mode, road quality has more influence on Indonesian trade (import volume.

The impact of the infrastructure quality does not only affect both export and import trades, but also affects the transportation costs Therefore, the central and local governments are required to allocate a budget through the state budget and the regional budget, and the budget should be minimally the same as that before the crisis of 1997/1998 which accounts for about 5 to 8 percent of GDP by first identifying the infrastructure priorities. Since the coefficient of port infrastructure quality is more influential to trade, improvement efforts on ports should be a priority, especially in relation to the availabilities of infrastructure and facilities for docking/bersandar, unloading and storage, coordination and efficiency of the agencies involved and the dwelling time as well.

\section{REFERENCES}

Badan Pusat Statistik (2000-2011), Indonesian Statistic, 2000-2011, Jakarta.

Chang, R., L. Kaltani and N.V. Loayza (2009), "Openness Can Be Good for Growth: The Role of Policy Complementarities," Journal of Development Economics, 90(1), 33-49. 
Chen, P.P. and R. Gupta (2006), “Openess Growth,” Working Papers Series 2006-2003, Department of Economics, University of Pretoria.

Davis, D.R. and D.E. Weinstein (2003), "Market Access, Economic Geography and Comparative Advantage: An Empirical Test, Journal of International Economics, 59, 123.

Deardorff, A.V. (1995), "Determinants of Bilateral Trade: Does Gravity Work in a Neoclassical World?," NBER Working Paper No. 5377.

Department of Transportation (2008), Sea and Air Transportation Statistics, Ministry of Transportation, Jakarta.

Directorate General of Highways (Direktorat Bina Marga) (2010), Rencana Strategis 2010 2014, http://www.pu.go.id/uploads/services/infopublik20120419175755.pdf. Accesed on 11 February 2012.

Hummels, D. (2007), "Transportation Costs and International Trade in the Second Era of Globalization," Journal of Economics Perspectives, 21(3), 131-154.

Kelejian, H. and D. Robinson (2006), "The importance of transportation infrastructure to factor and factors prices," TED2006 Transportation Research Board Conference on Transportation and Economic Development.

Kurmanalieva, E. (2006), “Transport Costs in International Trade," http://www.haveman.org/EITI07/Kurmanalieva.pdf accesed on 11 Jan 2012.

Limao, N. and A.J. Venables (2001), "Infrastructure, Geographical Disadvantage, Transport Costs and Trade," World Bank Economic Review, 15, 451-479.

Nordas, H.K. and R. Piermartini (2004), "Infrastructure and Trade," Staff Working Papers ERSD-2004-04, WTO, Geneva.

Pomfret, R. and P. Sourdin (2009), "Why Do Trade Costs Vary?" Research Papers No 2008-08, The University of Adelaide School of Economics, Australia.

Porto, G.G. (2005), "Informal Export Barriers and Poverty," Journal International Economicsi, 66(2), 447-470.

The Asia Foundation and LPEM-FEUI (2008), The Cost of Moving Goods: Road Transportation, Regulations and Charges in Indonesia, Jakarta.

UNCTAD (2012), Review of Maritime Transport 2012, UNCTAD, Geneva.

World Bank (2011), Doing Business: Making a Difference for Entrepreneurs, The International Bank for Reconstruction and Development, Washington DC.

World Economic Forum (2011), The Global Competitiveness Report, Switzerland.

WTO (2012), World Trade Report, World Trade Organization, Switzerland.

Yeaple, S. and S.S. Golub (2002), "International Productivity Differences, Infrastructure and Comparative Advantage," mimeo, University of Pennsylvania, December. 